\title{
確認場面を模擬した意思決定課題の開発 一作業版IGTとの比較-
}

○北村 康宏（鉄道総合技術研究所）

河地 庸介（東北福祉大学）

阿部 千裕（東北福祉大学 感性福祉研究所）

小野間 統子（鉄道総合技術研究所）

\section{Development of a decision making task simulating confirming situation \\ Yasuhiro KITAMURA (Railway Technical Research Institute), \\ Yousuke KAWACHI (Tohoku Fukushi University) \\ Chihiro ABE(Tohoku Fukushi University Kansei Fukushi Research Institute) \\ Noriko Onoma(Railway Technical Research Institute)}

\section{1. はじめに}

様々な作業場面で、現場作業者は連続的に何ら かの判断を繰り返しており、確実な情報が得られ ない中で意思決定が求められる。そのため、多く の事業者において意思決定時のリスク選好を抑制 するための教育訓練に取り組んでいるが、リスク 選好の傾向は個人差が大きく、個々人の意思決定 の特徽を把握できる評価指標が期待されている。

心理学の分野における個人の意思決定傾向を測 定する課題としては、Iowa gambling task ${ }^{1)}$ (以 降IGT）など既存の課題が複数存在するが、自身 が過去に得た報酬に基づいて行う将来的な報酬の 予測に重点を置いた意思決定課題が多かった。

一方、実際の作業場面では作業結果の確認を行 うか、など自身の作業結果に対する確信度が影響 する意思決定場面が多く存在している。そこで実 際の鉄道作業場面と同様に、自身が行った作業の 確認の有無に基づいた報酬の予測に重点をおく意 思決定課題 (コウテツ課題) が開発された2)。

本研究では、コウテツ課題について、課題成績 と f MRIによる報酬予測関連領域の計測結果を活 用し、その特性を明らかにすることを目的とする。 比較対象は報酬を作業量に変更した作業版IGTと した。作業版IGTは増減する対象が作業量である 点、また報酬予測という点でコウテツ課題と同一 である。相違点は、報酬予測に用いる情報源が、 IGTは過去の報酬であり、コウテツ課題は作業精 度の予測とそれに基づいた判断結果の報酬である。

\section{2. 方法}

\section{1 実験課題}

全ての刺激はPresentation（Neurobehavioral
Systems Inc., Albany, CA）で作成および制御さ れ、全ての課題はMRIスキャナー内で実施された。 1) コウテツ課題

課題は文字探索画面と確認の要否を判断寸 る画面の2段階で構成される ${ }^{2)}$ 。文字探索画 面では、9文字のカタカナ文字の中から、コ、 ウ、テ、ツの文字が複数あるか問われる。こ の画面が5回提示された後に確認の要否判断 画面に移行し、画面にYES-NOの文字が提示 される。YESを選択すると、直近の5問の文字 探索課題の正誤に関わらず、文字探索が2問 追加されると提示される。これは確認作業に よる手間を模擬したものである。一方でNOを 選択すると 5 問の文字探索課題に誤りがない 場合にのみ、課題の追加が発生しないと提示 される。5問の文字探索課題に 1 問でも誤り が有った場合には課題が10問追加されると提 示される。これは、作業にミスが無い場合に は確認を省略しても支障が無く、ミスがあっ た場合にのみ確認の省略が大きな悪影響を及 ぼすという状況を模擬している。

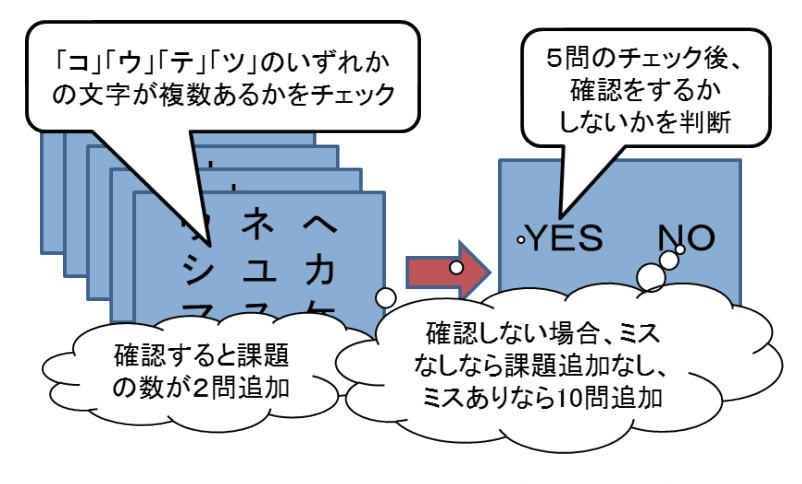

図1 コウテツ課題（1 試行分） 
5回の文字探索画面とその後の確認の要否判 断のセットが合計25回繰り返された時点で課 題は終了する。

\section{2）作業版IGT}

作業版IGTでは、ブロックを積み上げてタ ワーを作る企業4社に見立てた $\mathrm{A} ・ \mathrm{~B} ・ \mathrm{C} ・ \mathrm{D} の$ ラベルのついた4つのブロックが画面中央上 部に呈示され、出来るだけ高くブロックを積 み上げるように教示される。各選択肢の特徵 は先行研究 ${ }^{1)}$ と同様である。

\section{2 実験参加者}

20歳代から40歳代までの30名（男15名, 女15名, 平均年齢34.8歳）が参加した。全員右利きであり, 正常もしくは矯正視力を有していた。

\section{3. 結果}

\section{1 課題成績結果}

コウテツ課題で測定された確認の省略回数（No 選択回数）は平均 12.8 回（ $\mathrm{SD}=5.42$ 最小 4 回、 最大25回）であった。さらに分布は正規性を持つ ことが示された $(\mathrm{P}=0.12)$

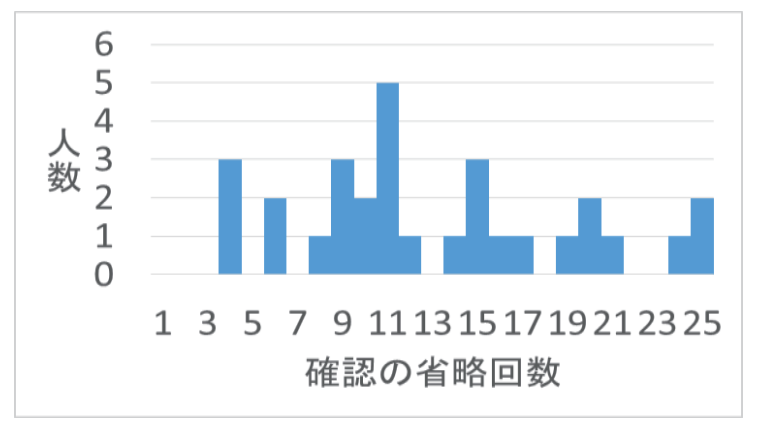

図2 省略回数の度数分布

さらに、作業用IGTのnet score（期待值の低い 選択肢の選択回数から期待值の高い選択肢の選択 回数の差分）とコウテツ課題の省略回数の相関を 検討したところ、有意な関係は見られなかった。

\section{2 fMRI分析}

3T MRI スキャナー (Siemens MAGNETOM Verio, Siemens，Erlangen，Germany）を用いて各実験参 加者の機能画像が取得された。解析には SPM12 (Wellcome Department of Imaging Neuroscience, London，UK）を用い、前処理、個人解析、および グループ解析を行った。閾值はvoxel levelで多 重比較補正なしのp $<.001$ に設定した。

\section{1）コウテツ課題の解析結果}

確認の要否判断時のリスク選好に伴う脳活動
を同定するために，高リスクである「NO」判断 と低リスクの「YES」判断とで比較し，「NO」判 断時に強い活動を示寸脳領域を特定した。その 際，リスク選好にのみ対応する脳活動を検出す るために，統制条件における「YES」選択に比 ベて「NO」選択で強い活動を示す脳領域を差し 引いた。その結果, 意思決定時のリスク選好に 関連して，両側の尾状核 (coordinates=-26, 18,$24 ; 10-624$, cluster size $=132 ; 14$, $\mathrm{Z}$ value $=4.37 ； 3.28 ）$ の賦活が有意であった。

\section{2）作業版IGTの解析結果}

同様に、作業版IGT実施時のリスク選好に伴 う脳活動を同定するために，期待值の低い高リ スク判断時と期待值の高い低リスク判断とで比 較し, 高リスク判断時に強い活動を示す脳領域 を特定した。その結果、尾状核 (coordinates $=-22,-8,16$, cluster size $=$ $6, Z$ value $=3.48 ）$ の賦活が有意であった。

\section{4. 考察}

課題成績から、コウテツ課題は幅広いリスク選 好の傾向を測定できる可能性が高いことが示され た。また、二つの課題成績に相関が無いことは、 二つの課題がリスク選好の異なる側面を測定して いる可能性を示しており、リスク選好の個人差の 検討においては予測に用いる情報源の違いを考慮 する必要性が示唆された。

fMRI分析結果からは、報酬予測に関わる線条体 の一部である尾状核の活動が両課題でみられ、報 酬予測という共通点を反映する結果を得た。今後、 課題成績を反映した分析を行うことで、相違点に ついても検証する予定である。

将来的には、コウテツ課題の文字探索画面での 成績を考慮した指標の開発などを行い、作業成績 とリスク選好の傾向を独立して把握できる、より 精緻な個人差の評価に取り組む予定である。

\section{参考文献}

1) Bechara, A et al: “ Insensitivity to future consequences following damage to human prefrontal cortex. ", Cognition, Vo1. 50, pp. 7-15, 1994.

2）北村 他：“判断ミス防止訓練に向けた意思 決定課題の基礎的評価”, 鉄道総研報告, Vol. 31, N0. 11, pp. 17-22, 2017. 